\title{
Pengembangan Film Pembelajaran IPS Untuk Penguasaan Kompetensi Mendeskripsikan Kegiatan Pokok Ekonomi (Studi Kasus: SMP Negeri 2 Sawan)
}

\author{
Putu Angga Adityastika ${ }^{1}$, Made Putrama ${ }^{2}$, Gede Aditra Pradnyana ${ }^{3}$ \\ Program Studi Pendidikan Teknik Informatika \\ Jurusan Teknik Informatika \\ Fakultas Teknik dan Kejuruan \\ Universitas Pendidikan Ganesha \\ E-mail: adityastikaangga@gmail.com ${ }^{1}$,made.putrama@undiksha.ac.id ${ }^{2}$,gede.aditra@undiksha.ac.id ${ }^{3}$
}

\begin{abstract}
Abstrak-- Pengembangan Film Pembelajaran IPS ini merupakan sebuah media pembelajaran berupa film yang meceritakan kehidupan sehari-hari sesuai dengan materi film yaitu Kegiatan pokok ekonomi. Film ini mengambil studi kasus di SMP Negeri 2 Sawan dan melibatkan siswa kelas VII sebagai responden. Penelitian ini bertujuan untuk (1) mengimplementasikan hasil rancangan pengembangan film pembelajaran IPS untuk penguasaan kompetensi mendiskripsikan kegiatan pokok ekonomi (2) mengetahui respon siswa terhadap Film pembelajaran IPS untuk penguasaan kompetensi mendiskripsikan kegiatan pokok ekonomi. Jenis penelitian yang digunakan dalam penelitian ini adalah penelitian dan pengembangan dengan desain pengembangan menggunakan model ADDIE. Film ini diimplementasikan dengan menggunakan aplikasi Adobe Premiere CS6 dalam proses video editing, Adobe Audition untuk edit audio, Adobe Encore untuk membuat menu DVD dan Adobe Photoshop CS6 untuk pembuatan desain keperluan film. Adapun hasil setelah dilakukan Uji ahli isi didapatkan hasil $88.66 \%$ dari kedua ahli isi. Hasil uji ahli media dari kedua ahli didapatkan hasil $84.66 \%$ dan hasil uji respon 91.31 $\%$ sehingga dapat disimpulkan film ini memiliki kriteria sangat positif.
\end{abstract}

Kata Kunci: Film Pembelajaran, Kegiatan Pokok Ekonomi, ADDIE

\footnotetext{
Abstract-- IPS Learning Film Development is a learning media in the form of films that tell everyday life in accordance with film material, namely the main economic activity. The film took a case study at Sawan Middle School 2 and involved VII grade students as respondents. This study aims to (1) implement the results of the design of the development of
}

social studies learning films for mastery of competency in describing the main activities of the economy (2) to find out the students' responses to social studies learning films for mastering the competence of describing the main economic activities. The type of research used in this study is research and development with development design using the ADDIE model. This film is implemented using the Adobe Premiere CS6 application in the process of video editing, Adobe Audition to edit audio, Adobe Encore to create DVD menus and Adobe Photoshop CS6 for making film design needs. The results after the content expert test were $88.66 \%$ of all content experts. The results of the media expert test from the two experts were $84.66 \%$ and the response test results were $91.31 \%$ so it can be concluded that this film has very positive criteria.

Keywords: Learning Film, Main Economic Activities, ADDIE

\section{PENDAHULUAN}

Pendidikan merupakan hal yang sangat penting bagi kemajuan bangsa. Pendidikan adalah usaha sadar dan terencana untuk mewujudkan suasana belajar dan proses pembelajaran agar peserta didik secara aktif mengembangkan potensi dirinya untuk memiliki kekuatan spiritual keagamaan, pengendalian diri, kepribadian, kecerdasan, akhlak mulia, serta keterampilan yang diperlukan dirinya dan masyarakat. Pembelajaran adalah kegiatan guru secara terprogram untuk membuat proses belajar secara aktif, yang menekankan pada penyediaan sumber belajar [1]. Pendidikan bertujuan untuk berkembangnya potensi peserta didik agar menjadi manusia 
yang beriman dan bertakwa kepada Tuhan Yang Maha Esa, berakhlak mulia, sehat, berilmu, cakap, kreatif, mandiri, dan menjadi warga negara yang demokratis serta bertanggung jawab, manusia memiliki hak yang sama untuk mendapatkan pendidikan. Untuk mencapai tujuan tersebut, pemerintah telah melakukan berbagai upaya untuk meningkatkan mutu pendidikan, baik dari segi kurikulum, fasilitas pendidikan serta melakukan pemerataan pendidikan [2]. Oleh karena itu pendidikan harus dikelola sebaik mungkin agar dapat memberikan pemahaman-pemahaman serta meningkatkan prestasi siswa.

Pemahaman dan kemampuan siswa dalam mendalami konsep pelajaran yang didapat tergantung bagaimana proses belajar mengajar dikelas serta sarana pendukung pembelajaran. Pada hakikatnya kegiatan belajar mengajar adalah suatu proses komunikasi. Melalui proses komunikasi, pesan atau informasi dapat diserap dan dihayati orang lain. Agar tidak terjadi kesenjangan dalam proses komunikasi perlu digunakan sarana yang membantu proses komunikasi yaitu media. Dalam proses belajar mengajar, media yang digunakan untuk meperlancar komunikasi belajar mengajar disebut media instruksional edukatif atau lebih sering disebut media pendidikan. Kata media berasal dari bahasa latin dan merupakan bentuk jamak dari kata medium yang secara harfiah berarti perantara atau pengantar. Sedangkan medoe adalah perantara atau pengantar pesan dari pengirim pesan ke penerima pesan [3].

Dalam proses pembelajaran, guru harus mempunyai kreatifitas dalam mengubah kondisi dan situasi pembelajaran yang lebih baik dari sebelum-sebelumnya, baik melalui cara mengajar, penggunaan media, penggunaan model pembelajaran, dan penggunaan metode pembelajaran yang dapat memacu motivasi siswa dalam mengikuti proses pembelajaran [4]. Dengan adanya perkembangan teknologi, akan semakin memudahkan guru dalam meningkatkan kreatifitas dalam proses pembelajaran. Penggunaan media pembelajaran dapat digunakan sebagai solusi dalam mengubah kondisi pembelajaran yang semula membosankan menjadi lebih menyenangkan dan kondusif, salah satunya adalah penggunaan media film pembelajaran yang merupakan media berbasis audiovisual yang menceritakan suatu kejadian sebagai pendukung dalam penyampaian materi sehingga lebih memudahkan guru dalam melakukan penjelasan materi dan memudahkan siswa dalam menangkap atau memahamai materi. Apabila proses belajar berjalan menyenangkan dan tidak membosankan, maka siswa akan mudah mengerti dengan materi yang disampaikan, sehingga dapat mengingkatkan atau memperbaiki hasil akhir yaitu prestasi belajar siswa.

Berdasarkan hasil wawancara yang telah dilakukan pada Kamis, 17 Februari 2016 dengan Bapak Made Widioka,
S.Pd selaku guru mata pelajaran IPS di SMP Negeri 2 Sawan, dijelaskan bahwa tantangan yang dihadapi selama proses pembelajaran adalah mempersiapkan media yang tepat dalam proses pembelajaran. Berdasarkan informasi dan data yang diperoleh peneliti dari Kepala Sekolah, pada tanggal 20 Oktober 2015 tepatnya pada malam hari, terjadi konsleting arus listrik, pada kejadian tersebut menyebabkan Lab Komputer dan ruang perpustakaan mengalami kebakaran, sehingga menyebabkan habisnya sumber belajar yang ada di SMP Negeri 2 Sawan. Hingga saat ini, media pembelajaran di sekolah masih terbatas pada buku paket bantuan dari dana bantuan operasional sekolah (BOS) yang jumlahnya masih sedikit, sehingga 1 buku paket digunakan oleh 2 orang sampai 3 orang siswa. Terkadang hal ini membuat suasana belajar terkadang ribut dan kurang fokus dalam proses pembelajaran. Selain terkendala media, siswa kelas VII juga masih memiliki keinginan untuk bermain-main, sehingga guru cukup dibuat kerepotan untuk membuat siswa fokus dalam belajar.

Salah satu mata pelajaran yang didapat di sekolah menengah pertama yaitu mata pelajaran IPS. Dalam mata pelajaran IPS terdapat materi kegiatan pokok ekonomi, yang diantaranya terdapat materi produksi, distribusi dan konsumsi. Menurut Bapak Made Widioka, S.Pd selaku guru mata pelajaran IPS di SMP Negeri 2 Sawan, materi ini sangat tepat jika dibuatkan media dalam bentuk film pembelajaran, karena nantinya akan dapat meningkatkan pemahaman siswa serta berpengaruh besar terhadap tingkah laku dan pola pikir siswa, seperti pemahaman terkait kegiatan produksi, pengetahuan tentang distribusi serta pemahaman terkait segala jenis kegiatan konsumsi sehari-hari. Contohnya pada materi konsumsi, pada saat siswa SMP masih wajib membayar SPP, pernah terjadi beberapa kasus siswa menyalahgunakan uang dari orang tua. Dengan alasan tersebut, beliau mengharapkan dengan adanya tayangan secara realita terkait dampak perilaku konsumtif atau sejenisnya bisa mengubah pola pikir dan juga pemahaman mereka. Berdasarkan wawancara yang dilakukan peneliti kepada salah seorang siswa kelas VII A yang bernama Ketut Lia Mahayani, materi IPS banyak hafalan dan keterbatasan buku juga menyulitkan siswa untuk belajar dengan maksimal. Terkadang merasa jenuh karena media pembelajaran hanya diskusi-tanya jawab ataupun hanya berupa penyampaian materi dengan metode ceramah.

Penggunaan film dalam pembelajaran pernah dikembangkan oleh Wijayanti (2015) yaitu film yang berjudul Media Film Pada Pembelajaran Sejarah. Pada penelitian tersebut memberikan kesan positif bagi siswa Sekolah Menengah Pertama. Pemberian materi dengan menggunakan media film dapat meningkatkan hasil belajar siswa dan menambah wawasan siswa sehingga mata pelajaran IPS khususnya sejarah menjadi mata pelajaran yang diminati siswa. Selain itu Sugiarsana (2015) juga mengembangkan film 
pembelajaran yang berjudul Pengembangan Film Pembelajaran Musim Penghujan Pada Tema Peristiwa Alam Untuk Siswa Kelas I Sekolah Dasar Laboratorium UNDIKSHA Singaraja. Dari 70 siswa, 61 siswa menyatakan film pembelajaran musim penghujan masuk dalam kriteria sangat baik apabila dilihat dari segi kemampuan film untuk memotivasi semangat belajar siswa, menarik perhatian siswa, kejelasan cerita film yang mampu dipalPermgertians $\mathrm{Fi}_{\text {, }}$ menumbuhkan konsentrasi belajar, kejelasan materi yang disampaiakan melalui audio dan visual, ilustrasi kegiatan belajar yang mudah diikuti oleh siswa, materi yang disampaikan mudah dipahami, pengetahuan yang disampaian bersifat baru, menciptakan penglaman belajar yang nyata, sebagai salah satu sumber belajar yang inovatif, dan membantu siswa untuk belajar secara mandiri [5].

Dari penelitian relevan di atas dapat dikatakan bahwa film bisa dijadikan salah satu alternaltif media pembelajaran yang bisa memperkaya kreasi pembelajaran serta dapat menambah wawasan, motivasi dan minat belajar siswa dengan cara yang menyenangkan dan tidak merasa jenuh dan bosan dalam pembelajaran. Dibandingkan media pembelajaran lain, film pembelajaran juga dapat menyampaikan isi yang ingin disampaikan sehingga mencapai sasaran dan tujuan yang ingin dicapai serta mendekatkan siswa dengan kondisi sebenarnya sehingga pengalaman siswa jadi lebih konkret. Selain itu, hasil dari penyebaran angket yang peneliti lakukan pada hari Kamis 4 Maret 2016, dilakukan di 2 kelas yaitu kelas VII A dan VII B dengan total 64 siswa, 95,70\% menyatakan setuju menggunakan film sebagai media pembelajaran karena dapat menambah semangat dalam mengikuti pembelajaran.

Berdasarkan permasalahan yang dihadapi guru dan siswa kelas VII di SMP Negeri 2 Sawan, peneliti tertarik untuk melakukan penelitian pengembangan film pembelajaran dengan judul "Pengembangan Film Pembelajaran IPS Untuk Penguasaan Kompetensi Mendiskripsikan Kegiatan Pokok Ekonomi (Studi Kasus: SMP Negeri 2 Sawan)". Dengan adanya film pembelajaran ini, diharapkan dapat memberikan impact atau dampak yang signifikan kepada siswa kelas VII tentang pemahaman terhadap materi IPS salah satunya materi kegiatan pokok ekonomi dan menarik minat serta antusiasme siswa dalam mengikuti pelajaran.

\section{KAJIAN TEORI}

\subsection{Pengertian Media Pembelajaran}

Kata media berasal bahasa latin yang merupakan bentuk jamak dari medium, secara harfiah berarti perantara atau pengantar. Media adalah sesuatu yang membawa informasi antara sumber (source) dan penerima (receiver). Jadi dapat disimpulkan bahwa media merupakan perantara yang dapat menyampaikan informasi kepada penerima. Media pembelajaran adalah alat bantu berupa fisik maupun nonfisik yang senagaja digunakan sebagai perantara antara guru dan siswa dalam memahami materi pembelajaran agar lebih efektif dan efisien [6].

\subsection{Film Pembelajaran}

Secara harfiah, film adalah cinematographie yang berasal dari kata cinema (gerak), tho atau phytos (cahaya), dan grafie atau grhap (tulisan, gambar, citra). Jadi jika diartikan, film berarti melukis gerak dengan cahaya. Agar dapat melukis gerak dengan cahaya menggunakan alat khusus yang biasa disebut kamera [7]

Film adalah seni budaya yang merupakan pranata social dan media komunikasi massa yang dibuat berdasarkan sinematografi dengan atau tanpa suara dan dapat dipertunjukkan [8].

\subsection{Software Pendukung}

Software yang digunakan yaitu Adobe Premiere CS6, Adobe audition, Adobe Encore CS6 dan Adobe Photoshop CS6.

\subsection{Materi Pokok Ekonomi}

Kegiatan pokok ekonomi ada tiga jenis, yaitu sebagai berikut [9].

\section{A. Produksi}

Produksi merupakan kegiatan manusia untuk menghasilkan barang yang bermanfaat guna memenuhi kebutuhan. Untuk melaksanakan produksi diperlukan sumber daya ekonomi. Sumber daya ekonomi sering disebut juga faktor-faktor produksi. Proses produksi memerlukan faktor penunjang. Misalnya proses pembuatan mebel. Faktor penunjang yang diperlukan dalam proses pembuatan mebel adalah kayu, tenaga kerja, alat-alat dan pemimpin yang mengatur pelaksanaan semua kegiatan. Setiap proses produksi memerlukan faktor penunjang, tanpa faktor penunjang produksi tidak akan berjalan. Faktor penunjang merupakan syarat mutlak bagi berlangsungnya proses produksi. Faktor penunjang dalam proses produksi dinamakan sumber daya ekonomi/faktor produksi.

Sumber daya ekonomi (faktor produksi) dapat dibedakan menjadi 4 macam, yaitu faktor produksi alam, faktor produksi tenaga kerja, faktor produksi modal dan faktor produksi kewiraswastaan (skill).

\section{B. Distribusi}

Barang dan jasa yang dihasilkan oleh produsen tidak digunakan sendiri oleh produsen. Sebagian besar atau seluruhnya dipersiapkan untuk orang lain. Untuk itu, perlu ada pihak yang mengantarkan barang dan jasa dari produsen ke 
konsumen. Pihak yang mengantarkan atau menyalurkan barang dan jasa disebut distributor. Konsumen harus membayar harga barang yang diterimanya, dengan kata lain, penyaluran itu melalui proses jual beli. Pelaksanaan distribusi bertujuan agar barang-barang hasil produksi sampai ke tangan konsumen dalam waktu yang setepat-tepatnya. Dengan kata lain, agar barang-barang hasil produksi mempunyai nilai guna karena kepemilikan, sehingga dapat dimanfaatkan oleh konsumen.

Sistem distribusi barang dan jasa berdasarkan langsung dan tidaknya hubungan antara produsen dan konsumen dibagi menjadi tiga, antara lain sebagai berikut.

\section{Konsumsi}

Konsumsi adalah kegiatan memakai atau menghabiskan barang untuk memenuhi kebutuhan. Konsumsi dalam artian luas yaitu pemakaian kegunaan barang untuk memenuhi kebutuhan sehingga kegunaan barang itu berangsur-angsur atau sekaligus habis.orang yang memakai barang dan kegunaan nya disebut konsumen, pemakai atau pengguna. Konsumsi bertujuan untuk memenuhi berbagai macam kebutuhan hidup sehingga mencapai kepuasan maksimal.

Jumlah barang yang dikonsumsi seseorang berbeda dengan orang lain. Jumlah barang yang dikonsumsi oleh suatu keluarga berbeda dengan keluarga lain.

\subsection{ADDIE}

ADDIE Model yang merupakan salah satu model desain pembelajaran sistematik. Penggunaan model ADDIE pada pengembangan produk multimedia untuk pembelajaran sudah dikenal secara luas [10].

\section{METODOLOGI PENELITIAN}

\subsection{Jenis Penelitian}

Untuk mengembangkan suatu media pembelajaran diperlukan persiapan dan rancangan yang diteliti. Dalam pengembangan ini model yang akan dikembangkan adalah mengacu pada model pengembangan Research and Development (R\&D). Menurut Sugiyono (dalam Rahardini, 2013) menyatakan bahwa metode penelitian dan pengembangan merupakan metode penelitian yang digunakan untuk menghasilkan produk tertentu dan menguji keefektifan produk tersebut.

\subsection{Desain Pengembangan}

Pada penelitian ini menggunakan model ADDIE. Model ini terdiri atas lima langkah, yaitu: (1) analisis (analyze), (2) perancangan (design), (3) pengembangan (development), (4) implementasi (implementation), dan (5) evaluasi (evaluation).

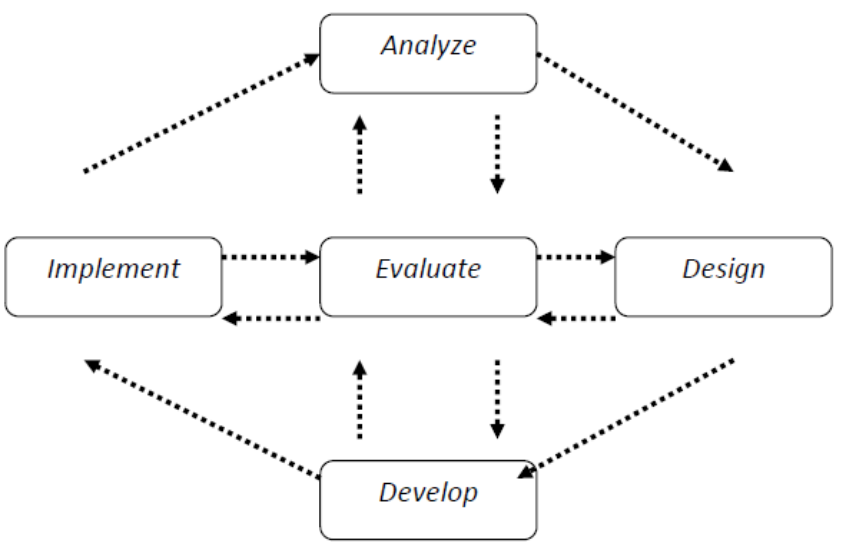

Gambar 1. Tahapan ADDIE Model (Sumber: Anglada, 2007) [11]

Adapun 5 tahapan yang akan diterapkan pada penelitian ini adalah sebagai berikut.

1. Tahap Analysis (Analisis)

Pada penelitian ini ada 3 teknik pengumpulan data yang dilakukan untuk mendapatkan data dan informasi yang dibutuhkan, yaitu teknik wawancara, instrumen angket, dan dokumentasi. Beikut merupakan teknik pengumpulan data yang dilakukan pada penelitian ini.

\begin{tabular}{|c|c|c|}
\hline No & $\begin{array}{l}\text { Teknik } \\
\text { Pengumpulan } \\
\text { Data }\end{array}$ & Data yang dikumpulkan \\
\hline 1 & Wawancara & $\begin{array}{l}\text { a. Karkteristik pembelajaran IPS } \\
\text { dengan materi pokok ekonomi } \\
\text { b. Kesulitan yang dihadapi siswa } \\
\text { pada saat proses pembelajaran } \\
\text { c. Keberadaan sumber belajar } \\
\text { siswa } \\
\text { d. Karkteristik siswa kelas VII } \\
\text { SMPN 2 Sawan }\end{array}$ \\
\hline 2 & Angket & $\begin{array}{l}\text { a. Data respon ahli materi } \\
\text { terhadap kesesuaian film } \\
\text { pembelajaran } \\
\text { b. Data respon ahli media } \\
\text { terhadap kesesuaian film } \\
\text { pembelajaran } \\
\text { c. Data respon siswa terhadap } \\
\text { film pembelajaran }\end{array}$ \\
\hline 3 & Dokumentasi & $\begin{array}{l}\text { Data pendukung pengembangan } \\
\text { film pembelajaran }\end{array}$ \\
\hline
\end{tabular}




\section{Tabel 1. Teknik Pengumpulan Data}

Pada tahap analisis ini penulis menganalisa masalah yang terjadi antara lain sebagai berikut.

Berdasarkan hasil wawancara kepada guru IPS sebelumnya, diketahui bahwa sebagian besar guru mengalami kesulitan dalam mempersiapkan media pembelajaran yang tepat untuk diberikan kepada siswa sesuai karakteristik siswa, ditambah lagi ketersedian buku paket disekolah sangatlah minim akibat insiden kebakaran di lab computer dan perpustakaan yang terjadi tahun 2015 yang membuat sumber belajar yang ada habis. Dalam proses mengajar, guru terkadang sulit menetukan metode mengajar dan media yang akan digunakan dalam proses pembelajaran. Sehingga guru lebih sering menggunakan metode diskusi tanya jawab dan metode ceramah. Hal ini membuat siswa terkadang sulit diatur dan ribut. Apalagi siswa kelas VII yang notabene masih baru menginjak sekolah menengah dan keinginan untuk bermain masih cukup tinggi. Tidak hanya menyulitkan guru saja, berdasarkan wawancara singkat dengan salah seorang siswa kelas VII yaitu Kadek Lia, ia pun merasa bosan dan jenuh dalam proses pembelajaran, karena secara umum guru yang ada di SMPN 2 Sawan mengajar dengan metode diskusi tanya jawab, ceramah, dan terkadang dengan quis. Apalagi mata pelajaran IPS merupakan mata pelajaran yang banyak hafalannya.

Berdasarkan analisis masalah tersebut, penulis berinisiatif untuk membuatkan media dalam bentuk film pembelajaran. Hal ini dikarenakan belum pernah ada media pembelajaran berupa audio-visual yang diterapkan di SMPN 2 Sawan. Kepala sekolah menyatakan setuju dengan penelitian ini dan sangat mendukung untuk penerapan media ini di SMPN 2 Sawan. Berdasarkan diskusi yang telah dilakukan dengan guru mata pelajaran IPS, beliau meminta untuk menyajikan materi kegiatan pokok ekonomi dalam bentuk film pembelajaran yang penulis tawarkan. Beliau mengungkapkan bawah materi ini sangat bagus jika dibuatkan dalam bentuk film karena secara umum manusia tidak lepas dari kegiatan ekonomi dalam kehidupan sehari-hari, seperti produksi, distribusi dan konsumsi. Namun siswa belum menyadari arti penting ketiga kegiatan pokok ekonomi itu, terutama pada masalah konsumsi. Dengan adanya film ini, diharapkan siswa dalam melihat gambaran secara nyata bagaimana dalam melakukan konsumsi secara bijak dan dampak dari perilaku konsumsi yang tidak wajar serta secara umum tentang kegiatan produksi dan konsumsi.

\section{Tahap Design (Perancangan)}

Film pembelajaran IPS untuk penguasaan kompetensi mendeskripsikan kegiatan pokok ekonomi merupakan sebuah film fiksi pendek non-animasi yang dapat ditonton oleh semua umur. Film pembelajaran ini terdiri atas 3 episode, yaitu film tentang produksi, distribusi dan konsumsi. Film ini akan dirancang dengan durasi per-episode sekitar 15 menit, karena film pembelajaran imi merupakan jenis film pendek, yang memiliki durasi ideal 15-45 menit. Cerita yang terkandung didalamnya disesuaikan dengan indikator pembelajaran IPS tentang materi kegiatan pokok ekonomi yang disajikan di setiap adegan film, baik melalui audio maupun visual/grafis. Di awal film akan terdapat menu untuk memilih film. Di setiap awal film akan di tampilkan indikator pembelajaran yang hendak dicapai dan di akhir setiap film akan berisi kesimpulan materi yang disajikan di film.

Dalam proses perancangan film pembelajaran ini, penulis membutuhkan beberapa data antara lain RPP, buku paket pegangan guru dan buku sekolah elektronik. Dari sumber data tersebut dapat diketahui indikator pembelajaran yang harus dicapai oleh siswa. Selain itu berdasarkan diskusi yang dilakukan penulis bersama guru mata pelajaran IPS yaitu Bapak Made Widioka, S.Pd, maka ditetapkan indikatorindikator pembelajaran yang harus dicapai oleh siswa untuk dikemas dalam bentuk media film pembelajaran.

Adapun indikator-indikator yang dimaksud dapat dilihat pada tabel 2 .

Tabel 2. Susunan Indikator Film Pembelajaran IPS tentang materi kegiatan pokok ekonomi

\begin{tabular}{|c|c|}
\hline Materi & Indikator \\
\hline Produksi & $\begin{array}{l}\text { 1. Mendefinisikan pengertian produksi } \\
\text { dan sumber daya ekonomi. } \\
\text { 2. Mengklasifikasi macam-macam } \\
\text { sumber daya ekonomi. } \\
\text { 3. Mengidentifikasi etika ekonomi } \\
\text { dalam memanfaatkan faktor-faktor } \\
\text { produksi dalam kehidupan suatu } \\
\text { usaha/bisnis. }\end{array}$ \\
\hline Distribusi & $\begin{array}{l}\text { 1. Mendefinisikan pengertian dan } \\
\text { tujuan distribusi. } \\
\text { 2. Mengklasifikasi sistem distribusi } \\
\text { beserta contohnya (langsung, tidak } \\
\text { langsung dan semi langsung) } \\
\text { 3. mendefinisikan etika ekonomi } \\
\text { dalam kegiatan distribusi }\end{array}$ \\
\hline Konsumsi & $\begin{array}{l}\text { 1. Mendefinisikan } \\
\text { konsumsi dan jenis barang-barang } \\
\text { yang dikonsumsi siswa dan } \\
\text { keluarga (harian, mingguan dan } \\
\text { bulanan). } \\
\text { 2. Menyusun skala prioritas dalam }\end{array}$ \\
\hline
\end{tabular}




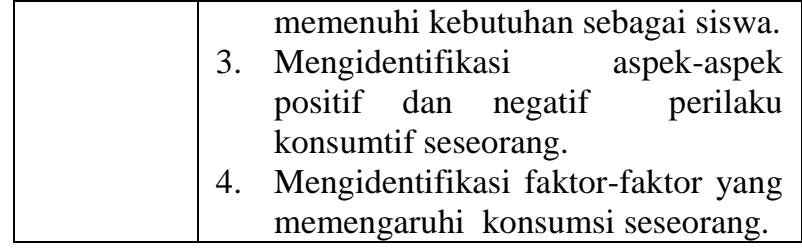

3. Tahap Development (Pengembangan)

Pada tahapan ini dilakukan proses produksi dan proses pasca produksi.

\section{a. Produksi}

Produksi merupakan proses yang paling menentukan keberhasilan dalam pembuatan film. Dalam proses pengambilan gambar dipimpin oleh seorang sutradara, orang yang paling bertanggung jawab dalam proses ini. Selain itu ada cameraman yang merekan gambar dan soundman yang mengatur audio pada saat proses shooting. Adapun crew dalam pembuatan film ini adalah Putu Angga Adityastika sebagai sutradara, cameraman 1 dan editor video, Kadek Agus Putra Negara sebagai cameraman 2, Gede Bayu Pratama sebagai soundman.

Pada proses ini penulis melakukan 2 tahapan yaitu tahapan shooting dan audio production. Pada tahapan shooting ini dilakukan dengan lebih dari 1 kamera, agar angle atau sudut pandang gambar yang didapat lebih bervariasi. Jenis kamera yang akan digunakan adalah kamera DSLR Cannon EOS 60D dan DSLR Cannon 1300D serta dibantu dengan adanya Tripod. Pasca Produksi

Pada tahap ini desain film yang berupa sinopsis dan storyboard akan dikembangkan. Dengan kata lain proses pembuatan film akan dilakukan pada tahap ini. Tahap pengembangan berada pada tahap produksi dan pasca produksi dalam tahapan-tahapan pembuatan film pembelajaran. Dalam tahapan pengembangan dilakukan beberapa hal, yang pertama pengambilan gambar. Pada tahap ini dilakukan pengambilan gambar video, sesuai dengan storyboard yang telah dibuat pada tahap desain. Pengambilan gambar film dibagi menjadi beberapa hari. Hal ini dilakukan karena proses pengambilan gambar dilakukan diberbagai tempat dan waktu yang berbeda. Adapun teknik pengambilan gambar dalam film pembelajaran ini adalah :

- Long Shot (LS). Pengambilan gambar dari jarak jauh tetapi tidak sejauh Establish Shot. Digunakan untuk penekanan terhadap lingkungan sekitar atau setting dalam scene
- Medium Shot (MS). Pengambilan gambar untuk membuat frame actor. Biasanya dilakukan dari pinggang ke atas. Medium shot biasa digunakan untuk membuat fokus terhadap dua orang actor yang saling berhadapan dan berinteraksi.

- Close-Up (CU). Pengambilan gambar dari jarak dekat. Biasanya fokus pada wajah, digunakan untuk memperlihatkan ekspresi wajah dari aktor. Memperhatikan detail obyek atau untuk mengarahkan audience pada suatu elemen yang dipentingkan.

- Over The Shoulder Shot (OS). Pengambilan gambar untuk mengambil gambar aktor melalui pundak aktor lain, digunakan ketika para aktor saling bertatapan muka satu sama lain.

- MCU (Medium Close Up Shot). Shot yang menampilkan sebatas dada sampai atas kepala.

- Knee Shot. Shot yang menampilkan sebatas lutut sampai dengan atas kepala

- TS (Total Shot) / FS (Full Shot). Shot yang menampilkan keseluruhan obyek.

- Two Shot, Three Shot,.. (Group Shot). Shot yang menampilkan dua orang/objek atau lebih terlepas dari jauh atau dekatnya pengambilan gambar.

Tahap selanjutnya adalah Audio Production. Pada tahap ini dilakukan pembuatan audio yang akan digunakan pada film. Pembuatan audio dilakukan dengan dubbing secara langsung dan akan dilanjutkan dengan melakukan editing audio.

Tahap selanjutnya adalah Editing Film. Pada tahap ini dilakukan editing pada film yang telah dibuat. Editing ini berupa penggabungan seluruh hasil dokumentasi film, pengisian musik latar yang telah dibuat pada tahap audio production, transisi antar video, penambahan efek animasi, color grading (penyelarasan warna), dan rendering film.

Pada tahap pascaproduksi peneliti menggunakan perangkat keras Laptop Acer Aspire E1-471 untuk proses editing, dan perangkat lunak Windows 1064 bit sebagai system operasi.

\section{Tahap Implementation (Implementasi)}

Pada Tahapan implementasi ini, penulis memproduksi film yang telah dikembangkan dalam bentuk DVD. Film pembelajaran IPS ini akan di uji cobakan di Kelas VII di SMP Negeri 2 Sawan sehingga diketahui respon siswa terhadap film pembelajaran IPS Untuk Penguasaan Kompetensi Mendiskripsikan Kegiatan Pokok Ekonomi. 
Pada tahap implementasi ini akan dilakukan uji ahli, yaitu uji ahli isi dan uji ahli media sebelum film di uji cobakan kepada siswa. Uji ahli ini bertujuan agar film yang dibuat sesuai dengan standar isi yang digunakan oleh guru mata pelajaran dan kelayakan film sebagai media pembelajaran. Uji ahli akan dilakukan setelah film selesai dibuat. Setelah dilakukan uji ahli, maka akan dilakukan uji responden. Sebelum di implementasikan ke siswa, peneliti melakukan pelatihan penggunaan film kepada Bapak Made Widioka, S.Pd. Kemudian dilakukan uji responden, ini bertujuan agar siswa dapat memberikan penilaian terhadap kelayakan film.

\section{Tahap Evaluation (Evaluasi)}

Dalam penelitian ini, evaluasi formatif terus dilakukan di setiap tahap pengembangan. Adapun evaluasi formatif yang dilakukan, diantaranya:

\section{a. Evaluasi pada Tahap Analisis}

Evaluasi pada tahap analisis dilakukan dengan cara pengisian instrument evaluasi analisis oleh dosen pembimbing.

b. Evaluasi pada Tahap Perancangan

Evaluasi pada tahap design dilakukan dengan cara pengisian instrument evaluasi design oleh dosen pembimbing dan guru bidang studi IPS.

c. Evaluasi pada Tahap Pengembangan

Evaluasi pada tahap development dilakukan dengan cara pengisian instrument evaluasi development oleh dosen pembimbing.

d. Evaluasi pada Tahap Implementasi

Evaluasi pada tahap implementation dilakukan dengan cara pengisian angket uji ahli dan angket respon penonton. Evaluasi pada tahap implementasi adalah evaluasi akhir pada Film Pembelajaran IPS. Berikut uji evaluasi pada tahap implementasi:

- Uji Ahli Isi

Uji ahli isi dilakukan untuk mengetahui kesesuaian isi Film Pembelajaran IPS dengan RPP dan materi pelajaran. Instrument uji ahli isi pada Film Pembelajaran IPS terlampir. (dapat dilihat pada Lampiran 14)

- Uji Ahli Media

Uji ahli media dilakukan untuk mengetahui apakah film yang dikembangkan siap untuk dipublikasikan atau tidak. Instrument uji ahli media pada Film Pembelajaran IPS terlampir. (dapat dilihat pada Lampiran 15)

- Uji Respon

Uji Respon dilakukan untuk mengetahui kepuasan penonton dan tanggapan penonton tentang Film Pembelajaran IPS. Uji respon penonton dilakukan dengan cara menyebarkan angket setelah menonton Film Pembelajaran IPS.

Penilaian hasil dari uji ahli isi, media dan responden dihitung dengan Persamaan seperti yang dirumuskan oleh Kristiningrum (dalam Rahardini, 2013).

Presentase $=\frac{\text { Jumlah skor tiap item soal }}{\text { Jumlah skor maksimum tiap item soal }} \times 100 \% \ldots$

Untuk melihat kriteria atau tingkat pencapaian pengembangan film, presentase yang telah diperoleh kemudian ditransformasikan ke dalam kalimat yang bersifat kualitatif seperti kiteria pada tabel.

Tabel 3. Range Presentase dan kriteria kualitatif program yang dikutip dari Arikunto (dalam Rahardini, 2013)

\begin{tabular}{|l|l|l|}
\hline No & Interval & Kriteria \\
\hline 1 & $81 \%-100 \%$ & Sangat Baik \\
\hline 2 & $61 \%-80 \%$ & Baik \\
\hline 3 & $41 \%-60 \%$ & Cukup \\
\hline 4 & $21 \%-40 \%$ & Kurang \\
\hline 5 & $0 \%-20 \%$ & Kurang Sekali \\
\hline
\end{tabular}

\section{HASIL DAN PEMBAHASAN}

4.1 Hasil Penelitian

Pengembangan Film Pembelajaran IPS Untuk Penguasaan Kompetensi Mendiskripsikan Kegiatan Pokok Ekonomi (Studi Kasus: Smp Negeri 2 Sawan) menggunakan metode penelitian Research and Development $(R \& D)$ dengan model pengembangan ADDIE. Melalui tahapan pengembangan ADDIE telah dihasilkan sebuah film pembelajaran yang diharapkan dapat digunakan sebagai sumber dan media belajar siswa di sekolah dalam kegiatan pembelajaran IPS. Adapun hasil Pengembangan Film Pembelajaran IPS Untuk Penguasaan Kompetensi Mendiskripsikan Kegiatan Pokok Ekonomi (Studi Kasus: Smp Negeri 2 Sawan) dapat dilihat pada Gambar 2.

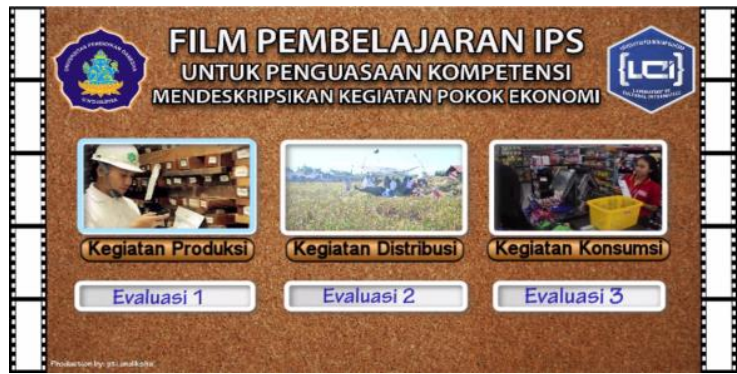


ISSN 2252-9063

Kumpulan Artikel Mahasiswa Pendidikan Teknik Informatika

(KARMAPATI)

Gambar 2. Tampilan Menu DVD

\subsection{Pembahasan}

Film pembelajaran IPS ini berperan sebagai media pembelajaran yang dapat membantu guru untuk mempermudah dalam menyampaikan materi tanpa menggantikan peran guru sebagai pengajar. Jadi peran guru dalam pembelajaran dengan menggunakan media berupa film pembelajaran ini adalah sebagai fasilitator yang memfasilitasi siswa dalam proses pembelajaran dan meluruskan pemahaman siswa yang salah.
Pengembangan film pembelajaran IPS ini menggunakan model ADDIE. Pada tahap analisis, penulis menganalisa beberapa permasalahan yang terjadi, yaitu kurangnya media pembelajaran yang mampu untuk mengembangan motivasi dan minat belajar siswa serta terbatasnya kemampuan guru dalam mengembangkan media pembelajaran yang bersifat nyata sesuai dengan materi pembelajaran. Berdasarkan permasalahan tersebut, penulis menganalisa rencana pelaksanaan pembelajaran serta buku paket pelajaran ilmu pengetahuan sosial untuk memperoleh informasi mengenai media pembelajaran yang perlu dikembangkan. Dari hasil wawancara dengan guru kelas menyatakan bahwa, perlunya pengembangan media pembelajaran yang nyata pada materi mata pelajaran IPS yaitu Kegiatan pokok ekonomi sehingga diharapkan dapat memenuhi kebutuhan siswa dalam kegiatan pembelajaran. Berdasarkan analisis kebutuhan tersebut, salah satu solusi yang ditawarkan penulis adalah Pengembangan Film Pembelajaran IPS untuk penguasaan kompetensi mendeskripsikan kegiatan pokok ekonomi.

Tahap desain dilakukan proses pra-produksi film yaitu mendesain cerita film untuk setiap kegiatan pembelajaran berdasarkan indikator pembelajaran. Guru dan penulis mendiskusikan indikator yang dipakai untuk dibuatkan film. Berdasarkan indikator tersebut dapat didesain berupa film pembelajaran yang terdiri atas 3 episode film yaitu episode 1 Kegiatan Produksi, episode 2 kegiatan distribusi dan episode 3 kegiatan konsumsi. Durasi untuk setiap episode yaitu 9 sampai 15 menit dan materi pembelajaran disampaikan di setiap adegan film, baik melalui audio, teks maupun visual/grafis. Sebelum melanjutkan pada tahap pengembangan penulis juga membuat sinopsis film, storyboard dan skenario film yang sudah dilengkapi dengan pemetaan indikator pembelajaran dibeberapa adegan. Setelah synopsis dan storyboard divalidasi oleh guru dan kedua dosen pembimbing, selanjutnya melakukan pemilihan pemeran pemain yang cocok untuk film pembelajaran ini. Kemudian dilanjutkan ke tahap berikutnya yaitu tahap pengembangan.

Tahap pengembangan dilakukan proses produksi dan pasca- produksi film. Pada tahap produksi, seluruh ide cerita, pemeran yang sudah terpilih akan diimplementasikan. Proses yang dalam kata lain bisa disebut dengan shooting (pengambilan gambar). Proses produksi film dimulai dari pengambilan gambar sesuai dengan synopsis dan storyboard, pengambilan suara untuk narasi film, kemudian mengumpulkan beberapa sumber gambar,audio dan video tambahan dari internet. Pada proses produksi penulis menggunakan perangkat keras seperti Kamera DSLR Cannon 1300D dan Tripod Takara. Setelah proses produksi film selesai, selanjutnya penulis menuju proses pasca-produksi film yaitu pengolahan atau editing terhadap hasil produksi baik itu 
gambar, video dan audio. Pada proses paca-produksi penulis menggunakan perangkat lunak Adobe Premiere Pro CS6 dan Adobe After Effects CS6 untuk editing video, Adobe audition untuk editing audio, Format Factory 2.90 untuk mengonvert format file. Adobe Encore CS6 untuk membuat menu DVD, dan Adobe Photoshop CS6 untuk desain sampul DVD. Setelah seluruh proses produksi dan pasca-produksi selesai, kemudian dilanjutkan ketahap berikutnya yaitu tahap implementasi.

Tahap implementasi merupakan tindak lanjut dari tahap pengembangan. Pada tahap implementasi penulis menggandakan/ memproduksi film yang telah dikembangkan dalam bentuk DVD. Tahap evaluasi dilakukan evaluasi secara formatif. Evaluasi formatif bertujuan untuk merevisi film sesuai dengan penilaian dan saran perbaikan yang diberikan oleh ahli isi, ahli desain, dan ahli media.

Hasil analisis yang dilakukan pada ahli isi melalui instrumen berupa angket menunjukan bahwa pada pengujian yang pertama kedua ahli isi menyatakan bahwa penggunaan font, jenis dan ukuran huruf kurang sesuai sehingga kedua ahli isi memberikan penilaian cukup setuju, selain itu kedua ahli isi juga memberikan saran perbaikan terhadap isi film pembelajaran. Hasil revisi kemudian dujikan kembali sehingga penilaian pada indikator penggunaan font, jenis dan ukuran huruf mendapat penilaian setuju dari kedua ahli. Berdasarkan analisis tersebut adapun hasil yang diperoleh dari analisis data dua ahli isi adalah sebesar $88.66 \%$ dan dapat dikonversikan pada kualifikasi sangat baik. Hasil tersebut menunjukkan bahwa kesesuaian film Pembelajaran IPS dengan aspek-aspek film sebagai media pembelajaran dilihat dari segi isi/materi yang disajikan dalam film pembelajaran sudah sesuai. Berikut adalah garfik tingkat pencapaian film berdasarkan seluruh uji ahli isi.

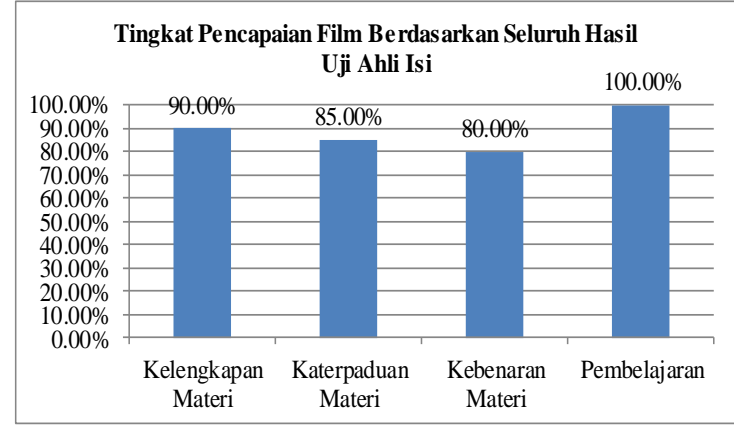

Gambar 3. Grafik Tingkat Pencapaian Film Uji Ahli Iis

Berdasarkan analisis yang dilakukan terhadap uji ahli media pembelajaran melalui instrumen berupa angket.
Berdasarkan analisis dari dua ahli media tersebut maka diperoleh hasil data dua ahli media adalah sebesar $84.66 \%$ dan ketika dikonversikan pada tabel konversi berada pada kualifikasi sangat baik. Hasil ini menunjukkan bahwa film Pembelajaran IPS sudah memenuhi aspek-aspek film sebagai media pembelajaran. Aspek-aspek film ini mencakup 2 aspek yaitu kesesuaian audio dan visual. Berikut adalah garfik tingkat pencapaian film berdasarkan seluruh uji ahli Media.

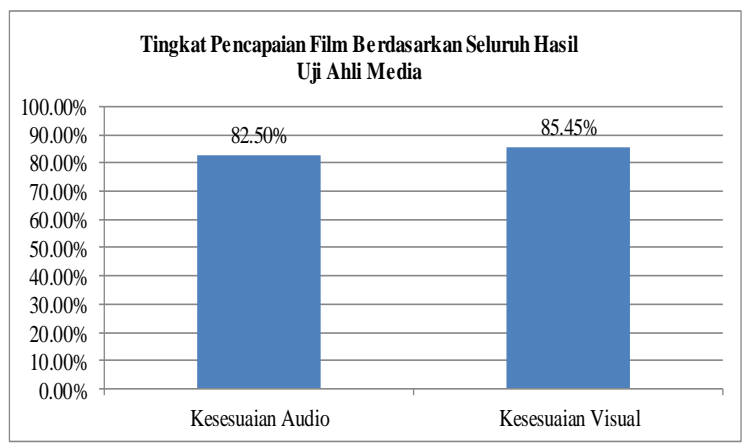

Gambar 4. Grafik Tingkat Pencapaian Ahli Media

Berdasarkan hasil analisis data hasil penyebaran angket respon terhadap penggunaan film pembelajaran IPS, dapat diimplikasi bahwa terdapat respon yang sangat positif dari guru dan siswa setelah penggunaan film pembelajaran IPS.

Berdasarkan hasil pengolahan data yang dilakukan terhadap data hasil penyebaran angket respon siswa setelah penerapan film pembelajaran dengan butir pernyataan sebanyak 20 butir pernyataan, diperoleh rata-rata hasil penyebaran angket respon siswa terhadap penggunaan film pembelajaran IPS adalah sebesar 91,59\% dengan kategori Sangat Baik. Respon negative juga didapat dari uji respon siswa, dimana pada butir 11 dan 15 mendapat persentase $67.27 \%$ dan $58.18 \%$. Pada butir 11 dijelaskana tentang apakah siswa leluasa bereinteraksi dengan temannya sat film ditayangkan. Pada butir 15 dijelaskan apakah siswa leluasa bertanya kepada guru saat media film ditayangkan. Pada 2 butir ini, bisa dilihat bahwa siswa hanya terfokus pada film saat film ditayangkan, namun hal ini kedepannya bisa diatasi apabila guru mampu memilih cara atau teknik yang tepat dalam menggunakan media film dalam kegiatan pembelajaran, sehingga suasana belajar menjadi lebih kondusif dan tujuan dari pembelajaran dapat tercapai.

Hasil penelitian film pembelajaran IPS ini sejalan dengan penelitian Sugiarsana (2015) tentang pengembangan film pembelajaran IPS yaitu sama-sama memperoleh penilaian layak dan mendapat respon sangat positif. Film ini dikembangkan melewati serangkaian validasi ahli isi, validasi alhi media dan uji coba produk/ uji responden untuk 
ISSN 2252-9063

Kumpulan Artikel Mahasiswa Pendidikan Teknik Informatika

(KARMAPATI)

Volume 8, Nomor 2, Tahun 2019

menghasilkan produk yang berkualitas. Dalam implementasinya pengembangan film pembelajaran Sugiarsana (2015) ini dilengkapi dengan menu film dan indikator pembelajaran, hanya saja yang membedakan pada pengembangan film pembelajaran IPS ini ditampilkannya inti materi yang dismpaikan pada beberapa scene film agar siswa lebih memahami materi selain dari mendengar, juga bisa melihat teks yang ditampilkan pada beberapa scene film. Kemudian dari segi desain pengembangan film pembelajaran sosiologi pada kompetensi mendeskripsikan nilai dan norma yang berlaku dalam masyarakat yang dikembangkan oleh Suandinatha (2015) mampu mencapai tujuan pembelajaran. Dalam film pembelajaran ini kegiatan pembelajaran disusun secara sistematis dilengkapi dengan materi yang disajikan dengan cerita dan gambar yang menarik agar siswa lebih termotivasi untuk belajar. Hal ini juga diterapkan pada film pembelajaran IPS, desain pengembangan film disajikan semenarik mungkin, fitur film pembelajaran disajikan dengan jelas dan lengkap, penggunaan huruf dan media disajikan dengan rapi dan mudah dipahami serta ditambah denganberbagai ilustrasi yang memepermudah siswa dalam mengaitkan film dalam perilakunya sehari-hari[12].

Adapun kendala yang dihadapi pada pembuatan film pembelajaran IPS ini adalah kurangnya alat yang memiliki kualitas bagus dalam hal audio, sehingga film ini masih memiliki kelemahan pada audio yaitu adanya sedikit noise di beberapa scene. Terlepas dari kendala tersebut, film pembelajaran ips masih dalam kriteria sangat baik setelah dilakukan beberapa uji yaitu uji ahli isi, ahli media dan ahli respon siswa.

Jadi berdasarkan hasil penilaian dari ahli isi, ahli media, dan respon siswa dapat disimpulkan bahwa film pembelajaran IPS masuk dalam kriteria sangat baik seperti yang disajikan dalam bentuk grafik pada Gambar.

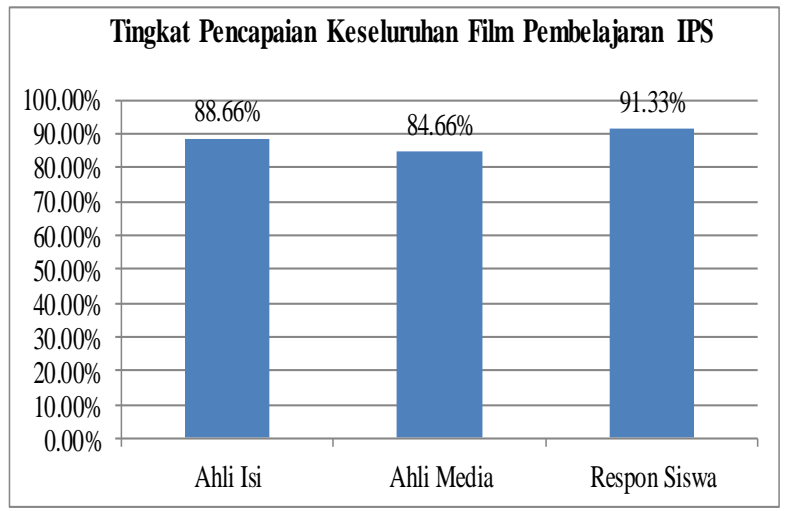

Gambar 5. Tingkat Pencapaian Film Pembelajaran IPS

\section{PENUTUP}

Kesimpulan yang diperoleh dari hasil dan pembahasan penelitian pengembangan Film Pembelajaran IPS , antara lain adalah sebagai berikut. Perancangan Film Pembelajaran IPS sudah berhasil dilaksanakan menggunakan model ADDIE. Berdasarkan hasil implementasi Film Pembelajaran IPS, menunjukan bahwa film ini sudah berhasil diimpelentasikan. Saran yang dapat diberikan penulis berdasarkan hasil penelitian dan pengembangan Film Pembelajaran IPS untuk penguasaan kompetensi mendeskripsikan keiatan pokok ekonomi adalah sebagai berikut. Pengembangan film pembelajaran IPS ini hanya dilakukan sampai pada tahap evaluasi formatif untuk mengetahui tingkat respon siswa terhadap film pembelajaran. Bagi peneliti selanjutnya film pembelajaran ini bisa dilanjutkan dengan melakukan penelitian eksperimen untuk mengetahui pengaruh film pembelajaran IPS terhadap hasil belajar siswa dalam pengimplementasiannya didalam kelas. Penggunaan film dalam kegiatan pembelajaran perlu memperhatikan pendekatan dan teknik yang tepat agar tercipta komunikasi yang baik antara siswa dengan siswa dan siswa dengan guru, sehingga suasana belajar menjadi lebih kondusif dan tujuan dari pembelajaran dapat tercapai. Hasil pengembangan film pembelajaran ini akan lebih baik apabila menggunakan peralatan produksi film yang lengkap dan dengan kualitas yang baik, terutama kualitas audio agar bisa lebih maksimal, sehingga diharapkan dapat menghasilkan film yang berkualitas.

\section{REFRENSI}

[1] Pasal 1 ayat 1 Undang-Undang Republik Indonesia Nomor 20 Tahun 2003 Tentang Sistem Pendidikan Nasional. Jakarta: Departemen Pendidikan Nasional.

[2] Pasal 3 Undang-Undang Republik Indonesia Nomor 20 Tahun 2003 Tentang Sistem Pendidikan Nasional. Jakarta: Departemen Pendidikan Nasional.

[3] Sadiman, A. S. 2007. Media Pendidikan. Jakarta: PT Raja Grafindo Persada.

[4] Wijayanti, N. E. 2015. "Media Film Pada Pembelajaran Sejarah". Universitas Negeri Gorontalo, Gorontalo 2015.Eko. (2013). Simulasi Digital. Kementrian Pendidikan dan Kebudayaan Republik Indoensia 2013.

[5] Sugiarsana, Juni. 2015. "Pengembangan Film Pembelajaran Musim Penghujan Pada Tema Peristiwa Alam Untuk Siswa Kelas I Sekolah Dasar Laboratorium UNDIKSHA Singaraja”. Universitas Pendidikan Ganesha, Singaraja Januari 2015. 
ISSN 2252-9063

[6] Musfiqon. (2012). Pengembangan Media dan Sumber Pembelajaran. Jakarta: Prestasi Pustakaraya.

[7] Riadi, M. 2012. Pengertian, Sejarah dan Unsur-unsur Film. http:/www.kajianpustaka.com/Pengertian, Sejarah dan Unsur-unsur Film-Pengertian dan Referensi.htm (diakses pada tanggal 22 februari 2016)

[8] Pasal 1 ayat 1 Undang-undang nomor 33 tahun 2009 tentang Pefilman. 2009. Jakarta

[9] Suparman.et.al. 2012. "IPS 1 untuk Kelas VII SMP dan MTS". Jakarta: PT Tiga Serangkai Pustaka Mandiri.

[10] Tegeh, I. M. 2013. "Pengembangan Bahan Ajar Metode Penelitian Pendidikan Dengan Addie Model". Universitas Pendidikan Ganesha.

[11] Anglada, D. 2007. "An Introduction to Instructional Design: Utilizing a Basic Design Model". Tersedia pada http://www.pace.edu/ctlt/newsletter (diakses tanggal 29 Maret 2016).

[12] Suandinatha, L. 2015. "Pengembangan Film Pembelajaran Sosiologi Pada Kompetensi Mendeskripsikan Nilai dan Norma Yang Berlaku Dalam Masyarakat Untuk Siswa Kelas X Di SMA Negeri 2 Singaraja". Universitas Pendidikan Ganesha, Singaraja Januari 2015. 